Gulawentah: Jurnal Studi Sosial

ISSN 2528-6293 (Print); ISSN 2528-6871 (Online)

Vol. 4, No. 2, Desember 2019, Hal 114-121

Tersedia Online: http://e-journal.unipma.ac.id/index.php/gulawentah

\title{
Upaya Peningkatan Motivasi dan Hasil Belajar IPS Melalui Kooperatif Model Jigsaw
}

\author{
Salamah dan Giyat \\ Program Studi Magister Pendidikan Ilmu Pengetahuan Sosial, Universitas PGRI Yogyakarta, \\ Jl. IKIP PGRI 1 Sonosewu, Yogyakarta, Indonesia \\ Email: wijayantininik6@gmail.com
}

\begin{abstract}
Abstrak
Penelitian ini bertujuan untuk mengetahui peningkatan motivasi dan hasil belajar IPS melalui pembelajaran kooperatif model Jigsaw bagi siswa kelas VI di SD Negeri Kapulogo. Subjek penelitian seluruh siswa kelas VI. Teknik pengumpulan data mengggunakan angket, observasi, wawancara dan tes. Data dianalisis menggunakan deskriptif kuantitatif dengan persentase. Berdasarkan hasil analisis data menunjukkan jumlah siswa tuntas belajar, pada prasiklus 13,33\%, siklus I 43,33\%, siklus II 76,66\%, dan siklus III 93,33\%. Sedangkan motivasi mengalami peningkatan dari rata-rata sedang menjadi tinggi pada siklus III. Hal itu menunjukkan bahwa pembelajaran kooperatif model Jigsaw dapat meningkatkan motivasi dan hasil belajar siswa pada mata pelajaran IPS.
\end{abstract}

Kata kunci: Motivasi; Hasil Belajar; Kooperatif JIGSAW

\section{Efforts to Increase Social Studies Motivation and Learning Outcomes through the Cooperative Jigsaw Model}

\begin{abstract}
This study aims to determine the increase in social motivation and learning outcomes through cooperative learning Jigsaw models for grade VI students in Kapulogo Public Elementary School. The research subjects were all grade VI students. Data collection techniques using questionnaires, observation, interviews, and tests. Data were analyzed using quantitative descriptive with percentages. Based on the results of data analysis shows the number of students completing learning, in pre-cycle $13.33 \%$, first cycle $43.33 \%$, second cycle $76.66 \%$, and third cycle $93.33 \%$. While motivation has increased from moderate to high in cycle III. It shows that the Jigsaw cooperative learning model can improve students' motivation and learning outcomes in social studies subjects.
\end{abstract}

Keywords: Motivation; Learning outcomes; JIGSAW Cooperative.

\section{Pendahuluan}

Pendidikan nasional bertujuan untuk mengembangkan potensi peserta didik agar menjadi manusia yang beriman dan bertakwa kepada Tuhan Yang Maha Esa, berakhlak mulia, sehat, berilmu, cakap, kreatif, mandiri dan menjadi warga negara yang demokratis serta

DOI: $10.25273 /$ gulawentah.v4i2.5558

Copyright ( 2019 Universitas PGRI Madiun

All rights reserved. 
bertanggung jawab. Pendidikan memiliki peranan yang sangat penting dalam meningkatkan kualitas sumber daya manusia, peningkatan mutu pendidikan akan tercapai apabila proses belajar mengajar yang diselenggarakan dikelas benar-benar efektif dan bermakna. Hamalik (2000), mengemukakan proses belajar akan mencapai hasil yang optimal apabila guru mampu memahami beberapa unsur dinamis dalamnya. Unsur-unsur dinamis yang perlu diperhatikan agar proses belajar siswa mencapai hasil optimal, yaitu (1) motivasi siswa, (2) bahan belajar, (3) alat bantu belajar, (4) suasana belajar, (5) kondisi subjeck yang belajar.

Sardiman (2012) mengemukakan fungsi motivasi (a) mendorong manusia untuk berbuat, (b) menentukan arah perbuatan, (c) menyeleksi perbuatan yakni menentukan perbuatan-perbuatan yang harus dikerjakan guna mencapai tujuan. Pembelajaran akan mencapai hasil yang optimal apabila guru mampu membangkitkan motivasi belajar pada siswa. Permasalahan yang dihadapi siswa kelas VI SD Negeri Kapulogo adalah hasil belajar siswa pada materi kenampakan alam dan keadaan sosial negara-negara tetangga nilai rata-rata 68 , dengan persentase ketuntasan hanya $13,33 \%$, pada saat proses belajar mengajar siswa terlihat pasif kurang bersemangat, metode pembelajaran yang diterapkan guru selalu ceramah dan diselingi tanya jawab, kegiatan belajar mengajar lebih berpusat pada guru sedangkan anak cenderung pasif, keadaan tersebut menyebabkan siswa malas belajar. Sehingga dapat disimpulkan motivasi dan hasil belajar siswa pada mata pelajaran IPS rendah. Hal tersebut dapat diatasi melalui penerapan pembelajaran kooperatif model Jigsaw. Rusman (2011) mengemukakan pembelajaran kooperatif merupakan bentuk pembelajaran dengan cara siswa belajar dan bekerja dalam kelompok-kelompok kecil secara kolaboratif, anggotanya terdiri dari empat sampai enam orang dengan struktur kelompok bersifat heterogen. Sanjaya (2006) mengemukakan bahwa dalam pembelajaran kooperatif model Jigsaw, siswa memiliki banyak kesempatan mengemukakan pendapat dan mengelolah imformasi yang didapat dan meningkatkan keterampilan berkomunikasi, setiap anggota kelompok bertanggung jawab atas keberhasilan kelompoknya dan ketuntasan merupakan bagian dari materi yang dipelajari.

Solihatin and Raharjo (2005) menyebutkan hasil penelitian yang dilakukan mengenai cooperatif learning: (a) Van Sickle menyebutkan pembelajaran dengan menggunakan cooperatif learning mampu mendorong tumbuhnya tanggungjawab sosial, berkembangnya ketergantungan positif, peningkatan dan kegairahan belajar, (b) Stahl menyebutkan pembelajaran dengan menggunakan cooperatif learning mampu mendorong tumbuhnya rasa setia kawanan dan keterbukaan diantara siswa, mendorong ketercapaian tujuan dan nilai-nilai sosial, (c) Webb menyebutkan pembelajaran dengan menggunakan cooperatif learning mendorong siswa lebih bergairah dan termotivasi dalam belajar IPS, (d) Etin Solihatin menyebutkan pembelajaran dengan menggunakan cooperatif learning meningkatkan minat mahasiswa belajar secara mandiri. Penelitian yang dilakukan (Asis, 2013; Masluchah, 2013; Mustamiin, 2016; Pratiwi, Kanzunnudin, \& Rondli, 2016; Umar, 2011) menunjukkan bahwa model pembelajaran kooperatif model Jigsaw dapat meningkatkan motivasi dan hasil belajar IPS.

Sehingga dapat ditarik kesimpulan bahwa pembelajaran dengan penerapan pendekatan kooperatif model Jigsaw dapat meningkatkan motivasi belajar, prestasi/hasil belajar, kegairahan belajar, serta mendorong tumbuhnya berbagai nilai-nilai sosial didalamnya. Rumusan masalah dalam penelitian ini adalah bagaimana upaya meningkatkan motivasi dan hasil belajar IPS melalui pembelajaran kooperatif model Jigsaw pada siswa kelas VI SD Negeri Kapulogo. Hipotesa dalam penelitian ini adalah, pembelajaran kooperatif model Jigsaw yang dilaksanakan secara tepat dapat meningkatkan motivasi dan hasil belajar siswa pada mata pelajaran IPS.

\section{Metode Penelitian}

Penelitian ini merupakan penelitian tindakan kelas (classroom action research). Kunandar (2008) penelitian tindakan dapat didefinisikan sebagai suatu penelitian tindakan (action research) yang dilakukan oleh guru sebagai peneliti di kelasnya atau bersama orang lain 
(kolaborasi) dengan jalan merancang, melaksanakan dan merefleksi kan tindakan secara kolaboratif dan partisipatif dan bertujuan memperbaiki atau meningkatkan mutu (kualitas) proses pembelajaran di kelasnya melalui suatu tindakan (treatment) dalam suatu siklus.

Tempat penelitian di SD Negeri Kapulogo dan subjek penelitian adalah siswa kelas VI, terdiri 16 siswa laki-laki dan 14 siswa perempuan. Penelitian tindakan kelas ini dilaksanakan dalam tiga siklus, siklus I dilaksanakan pada tanggal 21 Februari, II pada tanggal 28 Februari, siklus III dilaksanakan pada tanggal 7 Maret Tahun 2014. Arikunto and Suhardjono (2006) mengemukakan dalam penelitian tindakan kelas terdapat empat tahapan yang harus dilalui, yaitu perencanaan, pelaksanaan, pengamatan, dan refleksi.

Variabel dalam penelitian ini antara lain: motivasi belajar siswa, hasil belajar IPS dan pembelajaran kooperatif model Jigsaw. Motivasi belajar diukur dengan menggunakan angket, indikator motivasi belajar terdiri dari: (a) hasrat dan keinginan berhasil; (b) kebutuhan dan dorongan belajar; (c) harapan dan cita-cita masa depan; (d) penghargaan dalam belajar; (e) kegiatan yang menarik dalam belajar; (f) lingkungan belajar yang kondusif. Hasil belajar diukur melalui tes, kriteria ketuntasan minimal yang ditetapkan, yaitu 75, siswa yang telah mendapat nilai 75 atau lebih dinyatakan tuntas belajar. Pengukuran hasil belajar dilaksanakan melalui tes dan dilaksanakan pada setiap akhir siklus. Pengukuran ketepatan siswa dan guru dalam belajar mengajar dengan penerapan pendekatan kooperatif model Jigsaw diukur menggunakan tiga instrumen yaitu: lembar pengamatan aktivitas guru, pengamatan aktivitas siswa, dan wawancara.

Teknik analisis data dilakukan melalui diskriptif kuantitatif dengan persentase, agar data mudah dipahami serta dapat memberikan gambaran yang jelas maka disajikan dalam bentuk paparan naratif, tabel, maupun grafik. Penelitian ini menggunakan model uji coba alat ukur terpakai. Data yang telah diperoleh pada pelaksanaan tindakan kemudian dilakukan analisis untuk mengetahui reliabilitas dan validitas setiap itemnya. Indikator keberhasilan dalam penelitian ini adalah (a) motivasi belajar meningkat, yaitu 80\% siswa mencapai skor 90 keatas atau pada kategori motivasi tinggi; (b) Hasil belajar siswa meningkat, yaitu 80\% siswa telah mencapai Kriteria Ketuntasan Minimal (KKM) 75; (c) Pembelajaran kooperatif dapat diterapkan secara tepat oleh guru, (d) perolehan aktivitas guru pada kriteria tinggi.

\section{Hasil dan Pembahasan}

\section{Hasil}

Kondisi awal sikap siswa terhadap mata pelajaran IPS pada pra siklus dari 30 siswa adalah, 17 siswa atau 58\% menganggap IPS itu penting dan bermanfaat bagi kehidupan, sedangkan 13 siswa atau $42 \%$ menganggap IPS itu tidak penting dan tidak bermanfaat dalam kehidupannya. Keadaan ini bila tidak segera diatasi akan berakibat pada rendahnya motivasi dan hasil belajar siswa. Data yang diperoleh siswa pada pra siklus Motivasi belajar IPS rata-rata 69, hasil belajar rata-rata 68. Motivasi dan hasil belajar IPS pada pra siklus dapat dilihat pada gambar berikut.

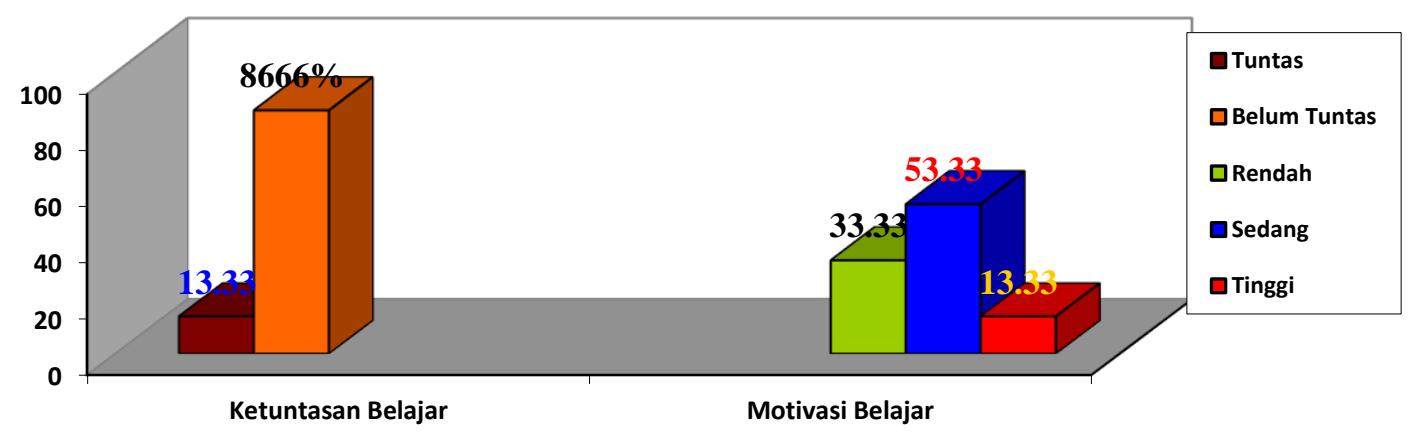

Gambar 1. Kategori Motivasi dan Hasil Belajar Pada Pra Siklus 


\section{Hasil Tindakan}

Pembelajaran IPS di SD Negeri Kapulogo yang dilaksanakan dengan menerapkan pendekatan kooperatif model Jigsaw dapat meningkatkan motivasi dan hasil belajar siswa, membangkitkan kegairahan siswa untuk belajar, adanya ketergantungan positif antar siswa, timbulnya semangat belajar dan guru dapat menerapkan pendekatan kooperatif secara tepat. Peningkatan motivasi belajar siswa dari pra silkus sampai dengan siklus II dapat dilihat pada grafik di bawah.

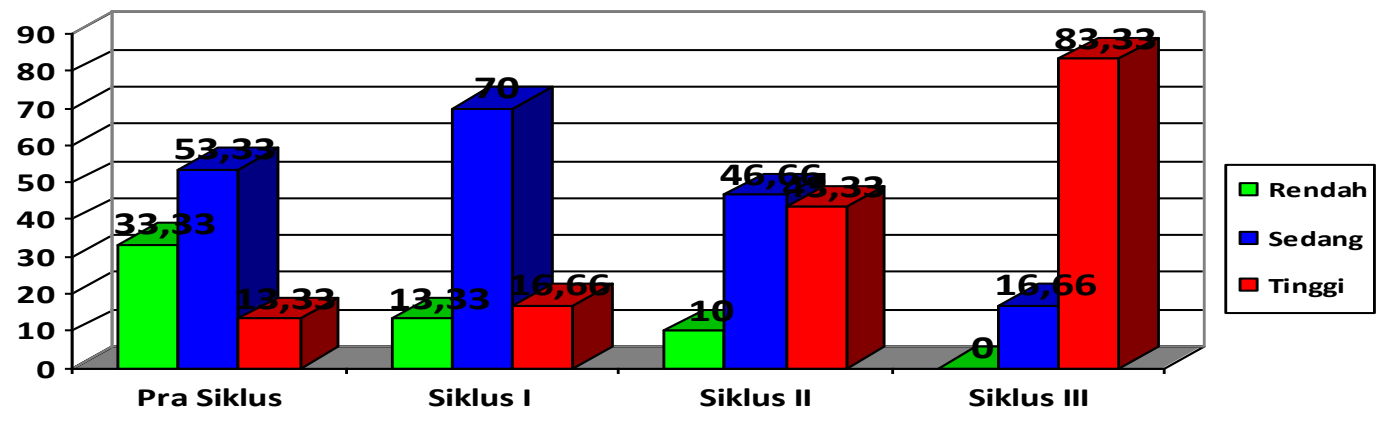

Gambar 2. Peningkatan Motivasi Belajar

Hasil observasi terhadap aktivitas siwa menunjukan pada siklus I 74,2\% , pada siklus II menjadi 78,2 meningkat 4,0, pada siklus III aktivitas siswa menjadi 82,7\% meningkat 4,5 Sedangkan aktivitas guru pada siklus I hanya $74,2 \%$ pada siklus II meningkat menjadi $79,16 \%$ atau meningkat 4,96, pada siklus II pencapaian aktivitas guru $79,16 \%$ pada siklus III meningkat menjadi $87,5 \%$ atau meningkat 8,3. Sehingga dapat dikatakan penerapan pembelajaran kooperatif model Jigsaw pada siklus III sudah diterapkan secara tepat.

Hasil penelitian ini membuktikan bahwa model pembelajaran kooperatif model Jigsaw dilaksanakan secara tepat dapat meningkatkan motivasi dan hasil belajar IPS, siswa menjadi tertarik dalam belajar, meningkatkan jiwa sosial anak, menumbuhkan ketergantungan positif, berlatih mengemukakan pendapat.

\section{Pembahasan}

Penelitian dilaksanakan dalam tiga siklus, pada setiap siklus terdiri dari empat tahap, yakni perencanaan, pelaksanaan, pengamatan dan refleksi seperti diuraikan berikut ini:

\section{Siklus I}

\section{Perencanaan}

Pada tahap perencanaanyang dilakukan peneliti antara lain: menyusun rencana pelaksanaan pembelajaran (RPP), membuat lembar kerja siswa, lembar evaluasi, membuat instrument yang dibutuhkan, membentuk mpok.

\section{Pelaksanaan}

Siklus I dilaksanakan pada hari Jumat tanggal 21 Februari 2018. Kegiatan awal yang dilakukan guru adalah memberikan penjelasan tentang langkah-langkah kegiatan pembelajaran kooperatif model Jigsaw. Pada awal kegiatan pembelajaran guru menyampaikan tujuan pembelajaran, menjelaskan langkah-langkah pembelajaran, mangadakan simulasi pembelajaran IPS dengan kooperatif model Jigsaw. Pada kegiatan inti guru membimbing siswa melakukan diskusi pada kelompok ahli sesuai dengan materi yang harus dipelajarinya, guru mengorganisir siswa melakukan diskusi dikelompok ahli, guru membimbing siswa menyampaikan hasil diskusi di kelompok ahli kepada teman-temannya di kelompok asalnya, guru mengarahkan siswa untuk mempresentasikan hasil diskusi. Pada akhir pembelajaran guru mengklarifikasi hasil diskusi yang telah dipresentasikan masing-masing kelompok, guru mengadakan evaluasi dan dilanjutkan guru menganalisis hasil evaluasi dan menentukan kelompok yang terbaik, kemudian guru memberikan penghargaan kepada kelompok terbaik. 


\section{Pengamatan}

Kegiatan pengamatan yang dilakukan kolaborator terhadap kinerja guru dalam menerapkan pembelajaran kooperatif model Jigsaw didapatkan data sebagai berikut: Skor aktivitas guru 89 sedangkan skor ideal 120 sehingga persentasenya 74,16\%, atau pada tingkat sedang. aktivitas siswa, skor 445 skor ideal 600 atau 74,2\% kategori sedang. Dari data aktivitas guru dan siswa dapat disimpulkan bahwa pembelajaran kooperatif belum terlaksana dengan tepat.

\section{Evaluasi dan Refleksi}

Pada akhir siklus guru mengadakaan evaluasi yang harus dikerjakan oleh siswa sendiri dan tidak boleh kerjasama dengan temannya dan membagikan lembar angket untuk didisi oleh siswa sesuai dengan yang dirasakan selama proses pembelajaran berlangsung. Ketuntasan belajar yang dicapai siswa pada siklus I dan kategori motivasi pada siklus I dapat dilihat pada grafik berikut ini:

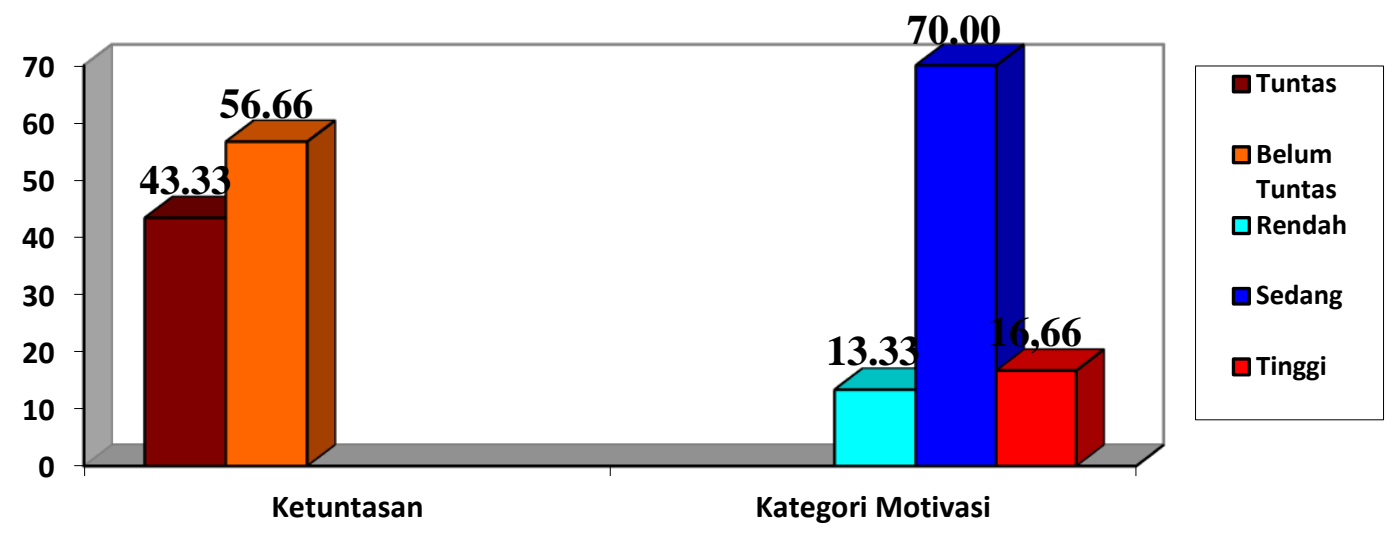

Gambar 3. Peningkatan Ketuntasan dan Motivasi Belajar Siklus I

Peningkatan ketuntasan belajar pada siklus I adalah sebagai berikut jumlah siswa yang tuntas belajar pada pra siklus 4 siswa, pada siklus I menjadi 13 orang meningkat 9 orang atau $30 \%$, sedangkan jumlah siswa dengan motivasi belajar kategori tinggi pada pra siklus ada 4 siswa siklus II menjadi 5 siswa meningkat 1 siswa atau $0,03 \%$.

Hasil temuan-temuan selama proses pembelajaran siklus I berlangsung antara lain: Rusmilatul kurang cocok dengan model pembelajaran kooperatif yang diterapkan guru, Akbar Bhakti Ananda merasa kurang cocok dengan Aditya dalam kelompoknya, sehingga berusaha mencari teman lain, Ulfi Sarofatun Markhamah lebih mantap bertanya pada guru dari pada dengan teman diskusi, Fuat Ngainul Yakin merasa tegang, atau kurang siap saat melakukan presentasi, guru belum dapat menerapkan model pembelajaran kooperatif model Jigsaw suasana pembelajaran belum efektif dan kondusif.

\section{Siklus II}

\section{Perencanaan}

Tahap perencanaan pada siklus II merupakan replaning siklus I dengan perbaikan pada bagian tertentu hal ini untuk mengatasi masalah-masalah yang ditemui serta mempertahankan keberhasilan yang dicapai pada siklus I. Tahap perencanaan yang dilakukan guru: menyusun rencana pelaksanaan pembelajaran (RPP), membuat lembar kerja siswa, lembar evaluasi, membuat instrument yang dibutuhkan dalam penelitian, mendamaikan perselisihan Akbar dan Adit, menjelaskan harapan guru dari penerapan pembelajaran kooperatif model Jigsaw.

\section{Pelaksanaan}

Siklus II dilaksanakan pada hari Jumat tanggal 28 Februari 2018, langkah-langkah pembelajaran sama pada siklus I, guru lebih intensif dalam membimbing tiap kelompok dalam 
diskusi dan mempresentasikan hasil diskusi. Kegiatan Awal dalam pembelajaran guru menyampaikan tujuan pembelajaran, dilanjutkan diskusi pada kelompok ahli, siswa kembali kekelompok asal presentasi hasil diskusi dikelompok ahli. Kegiatan diakhiri dengan evaluasi dan pemberian penghargaan.

\section{Pengamatan}

Pengamatan terhadap kegiatan pembelajaran siklus II, hasil pengamatan terhadap aktivitas guru pada siklus II, skor aktivitas guru 95 sedangkan skor ideal 120 sehingga persentasenya 79,16\%, atau pada tingkat sedang, dan aktivitas siswa, skor 469 skor ideal 600 atau 78,2\% kategori sedang. Pada siklus II ini siswa mulai terbiasa dengan pembelajaran kooperatif model Jigsaw, guru mampu menerapkan pembelajaran kooperatif Jigsaw dengan Baik.

\section{Evaluasi dan Refleksi}

Kegiatan yang dilakukan guru pada akhir siklus II adalah mengadakaan tes dan membagikan angket pada siswa untuk diisi sesuai apa yang dirasakan selama pembelajaran dengan pendekatan kooperatif model Jigsaw berlangsung. Data ketuntasan belajar dan kategori motivasi dapat dilihat pada grafik berikut ini:

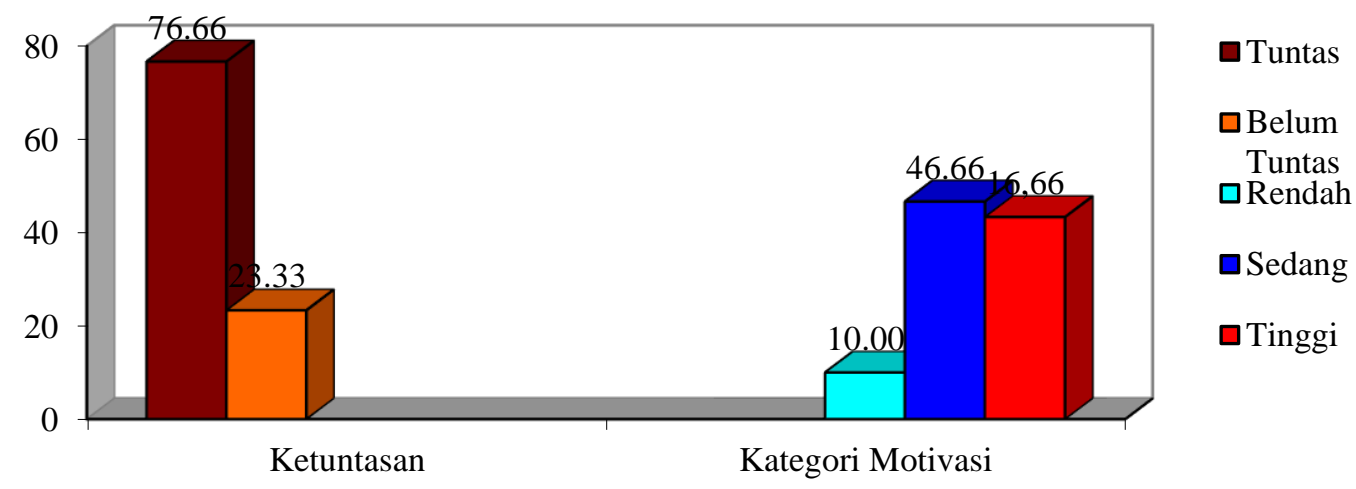

Gambar 4. Ketuntasan dan Motivasi Belajar Siklus II

Peningkatan ketuntasan belajar yang dicapai pada siklus II yaitu, jumlah siswa tuntas belajar pada siklus I sebanyak ada 13 siswa pada siklus II menjadi 23 siswa atau meningkat 10 siswa atau 33,33\%, sedangkan jumlah siswa dengan motivasi belajar kategori tinggi pada siklus I sebanyak 5 siswa pada siklus II menjadi 13 siswa meningkat 8 siswa atau 26,66\%.

Hasil temuan-temuan selama proses pembelajaran siklus II berlangsung antara lain: siswa mulai terbiasa melakukan diskusi, terjadi saling adu argumen dalam diskusi sehingga melatih siswa mengajukan pendapat, ketergantungan positif antar siswa terjalin dengan baik, ada siswa kurang percaya diri dengan pendapatnya, siswa mau menyampaikan hasil diskusi di kelompok asal, guru dapat menerapkan pembelajaran kooperatif model Jigsaw dapat dengan baik, guru sudah dapat menguasai pengelolaan kelas dengan baik, aktivitas guru dan siswa sudah menggambarkan penguasaannya terhadap langkah-langkah dalam pembelajaran kooperatif model Jigsaw. Hasil belajar dan motivasi siswa yang dicapai pada siklus II ini belum dapat mencapai indikator keberhasilan yang ditetapkan, maka penelitian dilanjutkan pada siklus III.

\section{Siklus III \\ Perencanaan}

Pada tahap perencanaan guru menyusun rencana pelaksanaan pembelajaran (RPP), membuat lembar kerja siswa, lembar evaluasi, lembar pengamatan aktivitas siswa dan lembar 
pengamatan aktivitas guru, memberikan pengarahan pada siswa agar belajar lebih giat tercapai tujuan yang diinginkan.

\section{Pelaksanaan}

Siklus III dilaksanakan pada hari Jumat tanggal 7 Maret 2018, pada tahap ini guru menyampaikan tujuan pembelajaran, siswa melakukan diskusi di kelompok ahli, siswa menyampaikan hasil diskusi di kelompok asal, siswa mempresentasikan hasil diskusi, guru mengklarifikasi hasil dipresentasikan kelompok, guru mengadakan evaluasi dan menentukan kelompok terbaik, guru memberikan penghargaan terhadap kelompok yang meraih prestasi tertinggi.

\section{Pengamatan}

Hasil pengamatan terhadap aktivitas guru pada siklus III didapatkan data, yaitu skor aktivitas guru 105 sedangkan skor ideal 120 sehingga persentasenya $87,5 \%$, atau pada tingkat tinggi, dan aktivitas siswa, skor 496 skor ideal 600 atau 82,7\% kategori tinggi. Pada siklus III siswa sudah merasa nyaman dengan pembelajaran kooperatif model Jigsaw, disamping itu guru sudah dapat menerapkan pembelajaran kooperatif Jigsaw secara tepat.

\section{Evaluasi dan Refleksi}

Data yang diperoleh dari pelaksanaan tindakan pada siklus III adalah motivasi dan hasil belajar, hasil wawancara dengan siswa. Data ketuntasan belajar dan kategori motivasi pada siklus III dapat dilihat pada grafik berikut ini:

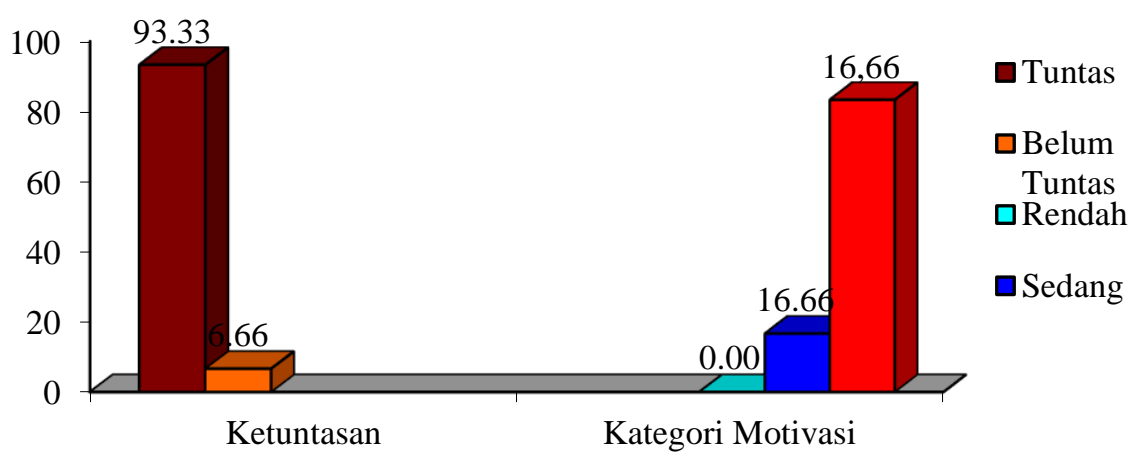

Gambar 5. Ketuntasan dan Motivasi Belajar Siklus III

Tabel di atas menjelaskan bahwa ketuntasan belajar pada siklus III sudah melampui pada indikator keberhasilan yang ditetapkan dalam penelitian ini yaitu penelitian dikatakan berhasil jika siswa yang tuntas mencapai $80 \%$ dari jumlah siswa yang ada di kelas VI.

Hasil temuan-temuan selama proses pembelajaran siklus III berlangsung antara lain: siswa sudah terbiasa dengan model pembelajaran kooperatif yang diterapkan guru, kerjasama terbangun dengan maksimal, siswa mulai mampu presentasi di depan kelas dengan baik, pembelajaran sudah berlangsung dengan tertib dan lancar peran guru juga semakin optimal, guru dapat menerapkan model pembelajaran kooperatif model Jigsaw secara tepat. Setelah dilakukan pembahasan dengan kolaborator maka peneliti dan kolaborator memperoleh kesimpulan sebagai berikut: guru sepakat mengakhiri kegiatan peenlitian sebab indikator keberhasilan yang ditetapkan sudah terpenuhi.

Berdasarkan wawancara yang dilakukan peneliti dengan Ulfi Sarofatun Markhamah, Niko Widinanda, dan Rusmilatul Muifaroh didapatkan data sikap/kesan siswa terhadap penerapan pembelajaran kooperatif model Jigsaw di kelas VI SD Negeri Kapulogo adalah sebagai berikut: pembelajarannya baik, membuat suasana belajar menjadi lebih berbeda dengan biasanya, siswa lebih kreatif dan antusias dan asik untuk bekerja kelompok, pembelajaran IPS sangat menarik, suasana tidak membosankan, menjadikan siswa aktif,dan mudah memahami materi pelajaran, siswa senang jika pembelajaran selanjutnya juga dengan pendekatan kooperatif model Jigsaw. 
Berbagai paparan data seperti diskripsi, tabel dan grafik yang telah tercantum di atas membuktikan bahwa pendekatan pembelajaran kooperatif model Jigsaw dapat meningkatkan motivasi belajar siswa, ketuntasan belajar, menumbuhkan jiwa sosial siswa, ketertarikan siswa untuk belajar, pembelajaran menjadi menyenangkan, menunmbuhkan rasa ketergantungan positif.

\section{Simpulan}

Berdasarkan hasil analisis data dapat diambil kesimpulan sebagai berikut : (a) penerapan pembelajaran kooperatif model Jigsaw yang dilaksanakan di SD Negeri Kapulogo dapat meningkatkan motivasi belajar IPS terbukti pada pra siklus siswa kategori tinggi 4 siswa atau $13,33 \%$, siklus I menjadi 5 siswa atau $16,66 \%$, siklus II menjadi 13 siswa atau 43,33\%, pada siklus III menjadi 25 siswa atau 83,33\%. (b) dapat meningkatkan hasil belajar siswa IPS, dibuktikan pra siklus siswa tuntas belajar 4 siswa atau 13,33\%, siklus I siswa tuntas belajar menjadi 13 siswa atau 43,33\%, siklus II siswa tuntas belajar menjadi 23 siswa atau 76,66\%, pada siklus III siswa yang tuntas belajar 28 orang atau 93,33\%, (c) Pembelajaran kooperatif model Jigsaw yang diterapkan pada pembelajaran IPS di SD Negeri Kapulogo secara tepat dapat menjadikan materi belajar mudah dipahami siswa, menumbuhkan jiwa sosial siswa, Membangkaitan ketergantungan positif anatas siswa.

\section{Daftar Pustaka}

Arikunto, S., \& Suhardjono, S. (2006). Penelitian tindakan kelas. Jakarta: Bumi Aksara.

Asis, B. (2013). Meningkatkan hasil belajar IPS dengan menggunakan model pembelajaran kooperatif tipe Jigsaw pada siswa kelas IV SDN 1 Gimpubia. JURNAL DIKDAS, 1(3).

Hamalik, O. (2000). Psikologi belajar dan mengajar: PT Sinar Baru Algensindo.

Kunandar, K. (2008). Penelitian Tinadakan Kelas : Langkah Mudah Sebagai Pengembangan Profesional GuruKunandar. Jakarta: Raja Grafindo.

Masluchah, Y. (2013). Penerapan Model Pembelajaran Kooperatif Tipe Jigsaw Untuk Meningkatkan Hasil Belajar Ips Siswa Kelas Iv Sekolah Dasar. Jurnal Penelitian Pendidikan Guru Sekolah Dasar, 1(2), 1-10.

Mustamiin, M. Z. (2016). Pengaruh Penggunaan Model Kooperatif Learning Tipe Jigsaw Terhadap Hasil Belajar IPS Di Tinjau Dari Motivasi Berpretasi. Jurnal Teknologi Pendidikan: Jurnal Penelitian dan Pengembangan Pembelajaran, 1(2), 65-76.

Pratiwi, I. A., Kanzunnudin, M., \& Rondli, W. S. (2016). Penerapan Model Pembelajaran Jigsaw Untuk Meningkatkan Hasil Belajar Ips Berbasis Multikultural. Jurnal Konseling Gusjigang, 2(1).

Rusman, R. (2011). Model-model pembelajaran: mengembangkan profesionalisme guru. Jakarta: Rajawali Pers/PT Raja Grafindo Persada.

Sanjaya, W. (2006). Strategi pembelajaran berorientasi standar proses pendidikan. In: Jakarta: kencana.

Sardiman, A. M. (2012). Interaksi dan Motivasi Belajar Mengajar. Jakarta: PT Raja Grafindo Persada.

Solihatin, E., \& Raharjo, R. (2005). Cooperatif Learning Penerapan dan pembelajaran IPS. Jakarta: Bumi Aksara.

Umar, E. (2011). Peningkatan hasil belajar siswa sekolah dasar melalui belajar kooperatif tipe jigsaw. Jurnal Inovasi, $8(03)$.

Gulawentah: Jurnal Studi Sosial Vol. 4, No. 2, Desember 2019, hal 114-121 